\title{
QUALITY OF MINIMALLY PROCESSED YAM (Dioscorea sp.) STORED AT TWO DIFFERENT TEMPERATURES ${ }^{1}$
}

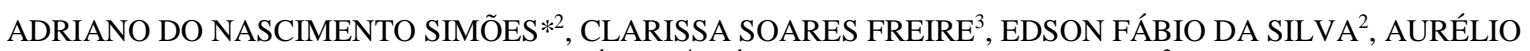 \\ PAES BARROS JÚNIOR ${ }^{4}$, SÉRGIO LUIZ FERREIRA-SILVA ${ }^{2}$
}

\begin{abstract}
This work studied the physical, chemical and biochemical alterations in minimally processed yam stored at two different temperatures, as well as the incidence of bacteria of the genus Pseudomonas. The experimental design was completely randomised in a $2 \times 8$ factorial design, with two storage temperatures (5 and $\left.10^{\circ} \mathrm{C}\right)$ and eight storage times $(0,2,4,6,8,10,12$ and 14 days). Experiments were in triplicate. Yam was selected, peeled and cut into slices of approximately $3 \mathrm{~cm}$ thickness. The slices were rinsed with water, sanitised and then drained in kitchen strainers. Approximately $300 \mathrm{~g}$ of the processed product were packed in nylon multilayers $15 \mu \mathrm{m}$ thick, $15 \mathrm{~cm}$ wide and $20 \mathrm{~cm}$ long. The packs were sealed, weighed and kept at 5 and $10 \pm 2^{\circ} \mathrm{C}$ for 14 days. Fresh weight loss, baking time, enzymatic activity of polyphenol oxidases, peroxidases and catalases, total soluble phenol content, and antioxidant capacity were evaluated, as well as visual analysis and incidence of Pseudomonas sp. Means of temperatures were compared by Tukey's test at 5\% significance. Yam storage at $5^{\circ} \mathrm{C}$ reduced weight loss and kept visual quality for longer; it also reduced cooking time and the activity of the enzymes polyphenol oxidase and peroxidase. In contrast, it promoted higher content of total soluble phenols, as well as a higher catalase activity and antioxidant capacity. During the storage time, there was no incidence of Pseudomonas sp. Minimally processed yam stored at $10^{\circ} \mathrm{C}$ may be sold for up to six days, and yam stored at $5^{\circ} \mathrm{C}$ for up to 14 days.
\end{abstract}

Keywords: Enzymatic activity. Post-harvest conservation. Dioscorea sp.. Pseudomonas sp.

\section{QUALIDADE DO INHAME (Dioscorea $\mathrm{sp}$.) MINIMAMENTE PROCESSADO CONSERVADO EM DUAS TEMPERATURAS}

\begin{abstract}
RESUMO - O objetivo deste trabalho foi estudar as alterações físico-químicas, bioquímicas e incidência de Pseudomonas sp. em inhame minimamente processado conservado em duas temperaturas. $\mathrm{O}$ delineamento experimental utilizado foi o inteiramente casualizado em esquema fatorial $2 \mathrm{x} 8$, referente as temperaturas $(5 \mathrm{e}$ $\left.10^{\circ} \mathrm{C}\right)$ e tempos de conservação refrigerada $(0,2,4,6,8,10,12$ e 14 dias), com três repetições. O inhame foi selecionado, descascado e cortado em rodelas de aproximadamente $3 \mathrm{~cm}$ de espessura. Essas rodelas foram enxaguadas em água, sanitizadas e drenadas em escorredores de cozinha. Aproximadamente $300 \mathrm{~g}$ do produto processado foram embalados em Nylon multicamadas de $15 \mu \mathrm{m}$ de espessura, com $15 \mathrm{~cm}$ de largura por $20 \mathrm{~cm}$ de comprimento. As embalagens foram seladas, pesadas e mantidas a 5 e $10 \pm 2{ }^{\circ} \mathrm{C}$ por 14 dias. Avaliou-se a perda de massa, tempo de cocção, atividade enzimática das polifenoloxidases e peroxidases, conteúdo de fenóis solúveis totais, capacidade antioxidante, análise visual e incidência de Pseudomonas sp. As médias entre as temperaturas foram comparadas pelo teste de Tukey a $5 \%$ de significância. A temperatura de $5{ }^{\circ} \mathrm{C}$ reduziu a perda de massa fresca e da qualidade visual, o tempo de cocção e a atividade das enzimas polifenoloxidases e peroxidases. Por outro lado, proporcionou maior conteúdo de fenóis solúveis totais e capacidade antioxidante. Ao longo da conservação, não foi observada incidência de Pseudomonas sp. O inhame minimamente processado, sob temperatura de $10^{\circ} \mathrm{C}$, pode ser comercializado por até 6 dias. A $5^{\circ} \mathrm{C}$, por até 14 dias.
\end{abstract}

Palavras-chave: Atividade enzimática. Conservação pós-colheita. Dioscorea sp.. Pseudomonas sp.

\footnotetext{
*Corresponding author

${ }^{1}$ Received for publication in 06/17/2014; accept in 05/13/2015.

Paper extracted from the master thesis of the third author.

${ }^{2}$ Unidade Acadêmica de Serra Talhada, Universidade Federal Rural de Pernambuco, Serra Talhada, PE, Brazil; adrianosimoesuast@gmail.com, edsonfabio@agronomo.eng.br, agrosergol@yahoo.com.br.

${ }^{3}$ Departament of Forest Sciences, Universidade Federal Rural de Pernambuco, Recife, PE, Brazil; clarissa.sfreire@gmail.com.

${ }^{4}$ Departament of Plant Sciences, Universidade Federal Rural do Semiárido, Mossoró, RN, Brazil; aurelio.barros@ufersa.edu.br.
} 


\section{INTRODUCTION}

In Brazil, the yam production (Dioscorea sp.) is about 244,000 tons annually, distributed over 25,000 hectares (FAOSTAT, 2011). The North-East has the largest production - about $90 \%$ - mainly in the states of Paraíba, Bahia, Alagoas, Sergipe, Pernambuco and Maranhão (SANTOS et al., 2007).

Commercialisation of yam is carried out without any beneficiation. Losses during storage are caused by insects, microorganisms and inadequate transport (PEIXOTO NETO et al., 2000). Moreover, the way the tubers are commercially kept, with soil and organic matter adhered to the surface, reduces their market value and adversely affects their storage life.

Minimal processing is an alternative to add value to the yam. Hereby, inedible parts are removed, leaving the product ready for consumption or preparation (HOWARD; GRIFFIN, 1993). However, the physical changes caused by minimal processing promote similar physiological responses as observed in plants under stress (BRECHT, 1995). There are reports of increased respiration rates, ethylene synthesis and enzymatic reactions (WATADA; ABE ; YAMUCHI, 1990), as well as dehydration intensification (BRECHT, 1995).

Yam darkens quickly after cutting. The first visible symptoms of deterioration are the presence of brownish stains on the surface. Dehydration in its tissues also results in starch deposition on the surface, causing a whitish appearance (DONEGÁ et al., 2013). In addition, there are changes in the attributes related to the quality of minimally processed foods, such as increased soluble solids, total soluble phenols, polyphenoloxidase activity and a $\mathrm{pH}$ reduction (FURTADO, 2013).

In another tuber, cassava (Manihot esculenta Crantz), quality loss occurs due to the increased production of reactive oxygen species (ROS), which promote the breakdown of cell membranes (XU et al., 2013). In its minimally processed form, cassava shows physiological changes during storage, such as a reduction in soluble solids (FREIRE et al., 2014) and total soluble phenols increased activity of polyphenoloxidases and peroxidases (FREIRE et al., 2015).

In recent studies on minimally processed yam, experiments with suitable packaging, edible coating, refrigeration temperatures (BRITO, 2011; ANDRADE et al., 2012; FURTADO, 2013; DONEGÁ et al., 2013), and alternative packaging were underaken (SILVA, 2014).

Suitable storage temperatures can minimise the damage caused by cutting, and reduncing storage temperature by $10^{\circ} \mathrm{C}$ leads to a two- or three-fold decrease in metabolic rates (BRECH, 1995). Controlling storage temperature can also minimise enzymatic activities (FATIBELLO-FILHO; VIEIRA, 2002). Refrigeration is a traditional way to reduce the activity of the enzyme polyphenoloxidase (SILVA et al., 2009). however, in supermarkets and commercial centres throughout Brazil, products are kept at temperatures above $5^{\circ} \mathrm{C}$ for economic reasons.

This work studied the physical, chemical and biochemical alterations of minimally processed yam stored at 5 and $10^{\circ} \mathrm{C}$ and the incidence of bacteria of the genus Pseudomonas.

\section{MATERIALS AND METHODS}

The study was conducted at the Universidade Federal Rural de Pernambuco/Unidade Acadêmica de Serra Talhada. Physiologically mature yam was purchased from producers in the region of Petrolina PE. The tubers were selected for size, visual appearance, and integrity, and damaaged tubers were discarded. They were then washed under running water and kept at $8^{\circ} \mathrm{C}$ for $24 \mathrm{~h}$.

The experimental design was a completely randomised design (CRD) with two factors: storage temperature $\left(5\right.$ and $10 \pm 2{ }^{\circ} \mathrm{C}$ ) and storage time after minimal processing $(0,2,4,6,8,10,12$ and 14 days).

We adapted the minimal processing methodology from Brito (2011). The tubers were peeled and cut into slices about $3 \mathrm{~cm}$ thick with stainless steel knives previously sanitised in chlorinated water with $200 \mathrm{mg} \mathrm{L}^{-1}$ of active chlorine ( $3 \%$ sodium dichloroisocyanurate dihydrate). For the initial rinse, slices were immersed in water at $5 \pm 2^{\circ} \mathrm{C}$ for $5 \mathrm{~min}$. Sanitasation was carried out by immersing about $2 \mathrm{~kg}$ of slices in chlorinated water with $200 \mathrm{mg} \mathrm{L}^{-1}$ of active chlorine for ten min. For the final rinse, slices were rinsed by immersing in chlorinated water with $5 \mathrm{mg} \mathrm{L}^{-1}$ of active chlorine for five min. Drainage was kept in dish strainers for ten minutes.

Approximately $300 \mathrm{~g}$ of slices were packed in multilayer nylon bags $15 \mu \mathrm{m}$ thick (NY 15), $15 \mathrm{~cm}$ wide and $20 \mathrm{~cm}$ long. The bags were sealed with a handmade sealer (40 $\mathrm{cm}$ pedal; plasmatic), weighted on a semi-analytical balance (ARD110; OHAUS $®$ ), and kept in vertical displays with forced air circulation (VB40W, Metalfrio) at 5 and $10 \pm 2{ }^{\circ} \mathrm{C}$ for 14 days. The following parameters were evaluated:

a) Fresh weight loss was determined gravimetrically by weighing the samples before storage and after different storage times on a semianalytical balance (ARD110; OHAUS $®$ ). The percentage of fresh weight loss was estimated from the difference between the initial and the final weight.

b) Baking time was estimated according to Andrade (2013). A stainless steel container with a vent and $2 \mathrm{~L}$ capacity was filled with $1 \mathrm{~L}$ water 
which was kept simmering on a cooking stove. When the water reached the boiling point, $100 \mathrm{~g}$ of yam slices were added and the container capped. Baking time of yam was defined as the time in minutes needed to soften the tissue so that a stainles fork can penetrate the centre of the slice without resistance.

c) Extraction and determination of polyphenoloxidase activity (PPO, EC 1.14.18.1) were carried out as described by Silva (1981) and adapted by Simões et al. (2015). A sample of $0.25 \mathrm{~g}$ with a height of $1,000 \mathrm{~mm}, 1000 \mathrm{~mm}$ width, and 5 $\mathrm{mm}$ thickness from the surface tissue located on the equatorial side of the yam slice. The sample was macerated in a mortar with $6 \mathrm{~mL}$ phosphate buffer $(0.2 \mathrm{M}, \mathrm{pH} 6.0)$ previously kept at $4^{\circ} \mathrm{C}$. The extract was then centrifuged (Universal $320 \mathrm{R}$; Hettich) with $9,000 \mathrm{~g}$ for $21 \mathrm{~min}$ at $4^{\circ} \mathrm{C}$. Determination of polyphenoloxidase activity was carried out following the methodology described by Coelho (2001). In brief, we used a mixture of $1 \mathrm{~mL}$ phosphate buffer $(0.2 \mathrm{M}, \mathrm{pH} 6.0)$ and $1.5 \mathrm{~mL}$ catechol $(0.2 \mathrm{M})$ as substrate. We then added $50 \mu \mathrm{L}$ of the enzymatic extract (supernatant). For the white one, we used the enzymatic extract boiled for $10 \mathrm{~min}$ in water bath (TE-054/te-056; Tecnal, SP, Brazil), while the other analytical procedures remained unchanged. Samples were spectrophotometrically measured (Libra S8; Biochrom) at $425 \mathrm{~nm}$ for $2 \mathrm{~min}$ with successive readings every $30 \mathrm{sec}$. Polyphenoloxidase activity was estimated using the molar extinction coefficient of $1300 \mathrm{mM} \mathrm{cm}^{-1}$ and results were expressed as $\mu$ mol per gram fresh weight $(\mathrm{FW})$ per minute.

d) Extraction and determination of the peroxidase activity (POD, EC 1.11.1.7) were carried out following the methodology described by Silva (1981) and adapted by Simões et al. (2015). We used a sample of $0.25 \mathrm{~g}$ with a height of $1,000 \mathrm{~mm}$, a width of $1,000 \mathrm{~mm}$, and a thickness of $5 \mathrm{~mm}$ from the surface tissue located on the equatorial side of the yam slice. The sample was macerated in a mortar with $6 \mathrm{~mL}$ phosphate buffer $(0.2 \mathrm{M}, \mathrm{pH}$ 6.0) previously kept at $4^{\circ} \mathrm{C}$. The extract was then centrifuged (Universal $320 \mathrm{R}$; Hettich) with 9,000 g for $21 \mathrm{~min}$ at $4^{\circ} \mathrm{C}$. Determination of peroxidase acticity was performed using a mixture containing 1 $\mathrm{mL}$ phosphate buffer and $10 \mathrm{~mL}$ enzymatic extract (supernatant). We then added $100 \mu \mathrm{L}$ guaiacol $(0.5 \%)$ and $100 \mu \mathrm{L}$ hydrogen peroxide $(0.08 \%)$ as substrate. Samples were spectrophotometrically measured (Libra S8; Biochrom) at $470 \mathrm{~nm}$ for $2 \mathrm{~min}$ with successive readings every $30 \mathrm{sec}$. For the white one, we used the enzymatic extract boiled for $10 \mathrm{~min}$ in a bain-marie (TE-054/te-056; Tecnal, SP, Brazil), while the other analytical procedures remained unchanged. Peroxidase activity was calculated using the molar extinction coefficient of $36.8 \mathrm{mM} \mathrm{cm}^{-1}$ and results were expressed as $\mu$ mol per gram fresh weight per minute.

e) Extraction and determination of catalase activity (CAT, EC: 1.11.1.6) was carried out according to the methodology described by Beers Júnior and Sizer (1952). We used a sample of $0.25 \mathrm{~g}$ with a height of $1,000 \mathrm{~mm}, 1000 \mathrm{~mm}$ width, and 5 $\mathrm{mm}$ in thickness from the surface tissue located on the equatorial side of the yam slice. The sample was macerated in a mortar with $6 \mathrm{~mL}$ potassium phosphate buffer $(50 \mathrm{mM}, \mathrm{pH} 7.0)$. The extract was then centrifuged (Universal $320 \mathrm{R}$; Hettich) with $9,000 \mathrm{~g}$ for $21 \mathrm{~min}$ at $4^{\circ} \mathrm{C}$. Determination of catalase acticity was performed using a mixture containing $2.95 \mathrm{~mL}$ potassium phosphate buffer with hydrogen peroxide $(20 \mathrm{mM})$ and $0.05 \mathrm{~mL}$ of the extract (supernatant). For the white one, we used $3 \mathrm{~mL}$ of potassium phosphate buffer, while the other analytical procedues remained unchanged. Samples were spectrophotometrically measured (Libra S8; Biochrom) at $240 \mathrm{~nm}$ for $3 \mathrm{~min}$ with successive readings every $30 \mathrm{sec}$; temperature was kept at $30^{\circ} \mathrm{C}$. Enzyme activity was calculated using the molar extinction coefficient of $36 \mathrm{M}^{-1} \mathrm{~cm}^{-1}$ and results were expressed as $\mathrm{nmol} \mathrm{H}_{2} \mathrm{O}_{2}$ per gram fresh weight per minute.

f) Total soluble phenols were extracted and quantified according to the methodology described by REYES et al. (2007), with modifications. We used a sample of $0.25 \mathrm{~g}$ with a height of $1,000 \mathrm{~mm}$, $1,000 \mathrm{~mm}$ width, and $5 \mathrm{~mm}$ in thickness from the surface tissue located on the equatorial side of the yam slice. The sample was macerated in a mortar with $10 \mathrm{~mL}$ pure methanol and kept in the dark at $4^{\circ}$ $\mathrm{C}$ for $24 \mathrm{~h}$. The extract was then centrifuged (Universal $320 \mathrm{R}$; Hettich) at 9,000 g for 21 minutes at $2{ }^{\circ} \mathrm{C}$. For the quantification of total soluble phenols we used $150 \mu \mathrm{L}$ of the extract (supernatant) diluted in $2,400 \mu \mathrm{L}$ distilled water and added $150 \mu \mathrm{L}$ Folin Cioucauteu $(0.25 \mathrm{~N})$. The mixture was homogenised in a tube shaker (Biomixer; model QL-901) for 3 min and $300 \mu \mathrm{L}$ of calcium carbonate $(1 \mathrm{~N})$ were added. The mixture was then stirred in a tube shaker (QL-901; Biomixer) and kept at room temperature for $2 \mathrm{~h}$. The preparation of the white one consisted in replacing the supernatant by $150 \mu \mathrm{L}$ of pure methanol while the other analytical procedures remained unchanged. Samples were spectrophotometrically measured (Libra S8; Biochrom) at $725 \mathrm{~nm}$ based on the calibration curve obtained with gallic acid. Results were expressed as mg per gram fresh weight.

g) Antioxidant capacity was determined in the same methanolic extract used to quantify total soluble phenols, following the methodology described by Brand-Williams et al. (1995) and modified by Sánchez-Moreno (2002). Determination of the antioxidant capacity was performed using a mixture containing $3,800 \mu \mathrm{L}$ of a 2,2-diphenyl-1picrylhydrazyl (DPPH) solution at $60 \mu \mathrm{M}$ with 200 $\mu \mathrm{L}$ of the extract (supernatant). The mixture was stirred in a tube shaker (QL-901; Biomixer) and kept in the dark for $30 \mathrm{~min}$. Samples were

Rev. Caatinga, Mossoró, v. 29, n. 1, p. 25 - 36, jan. - mar., 2016 
spectrophotometrically measured (Libra S8; Biochrom) at $515 \mathrm{~nm}$. As a control, we used a mixture containing $3,800 \mu \mathrm{L}$ of DPPH at $60 \mu \mathrm{M}$ and $200 \mu \mathrm{L}$ methanol. Antioxidant capacity was determined based on the calibration curve obtained with DPPH. Results were expressed as percentage of the radical scavenging activity (\% RSA).

h) Visual analysis was performed by a trained panel based on a subjective rating scale ranging from five to one. Five referred to slices with a characteristic white surface, no indication of brownish spots, and appearance and odour suitable for consumption. Four referred to slices with colour changes in relation to the initial day, but with a quality suitable for commercialisation. Three referred to slices with up to $10 \%$ of the surface consisting of brownish stains with moderate intensity; this was defined as the acceptance limit. Two referred to slices with approximately $50 \%$ of the surface consisting of brownish stains, unfit for human consumption and with gas build-up in the package. One referred to slices showing all the symptoms described above and alcoholic odour, totally unfit for human consumption (SILVA, 2014).

i) Incidence of Pseudomonas $\mathrm{sp}$ was determined as follows: two representative yam slices of each treatment were selected and photographed using a semi-professional digital camera (Nykon;
D3100 14.2 megapixels) coupled with a darkroom (CN-6; Vilber Lourmat) under ultraviolet light at 365 $\mathrm{nm}$ with a 1 x 6 Watts filter 1 x 6 Watts and $220 \mathrm{~V}$ $50 / 60 \mathrm{~Hz}$ (VL-6.1; Vilber Lourmat).

Analysis of variance (ANOVA) was carried out to test for differences among treatmens. Mean values between the two temperatures were compared by Tukey's test $(\mathrm{p}<0.05)$ using Sisvar ${ }^{\circledR}$ (version 5.0). Storage times were adjusted, when possible, to the regression equation using Table Curve ${ }^{\circledR}$ (2D version 5.1) (JANDEL SCIENTIFIC, 1991). Graphs were plotted using SigmaPlot ${ }^{\circledR}$ (version 10.0).

\section{RESULTS AND DISCUSSION}

We detected interactions between temperature and storage time for the parameters fresh weight loss, baking time, polyphenoloxidase and peroxidase activity, and antioxidant capacity. Still, it was observed effects of the isolated factors for visual analysis, catalase activity and content of total soluble phenols.

Fresh weight loss was increased in minimally processed yam kept at 5 and $10^{\circ} \mathrm{C}$. However, fresh weight loss in samples kept at $10^{\circ} \mathrm{C}$ was more intense with $0.35 \%$ and significantly different from day four of storage (Figure 1).

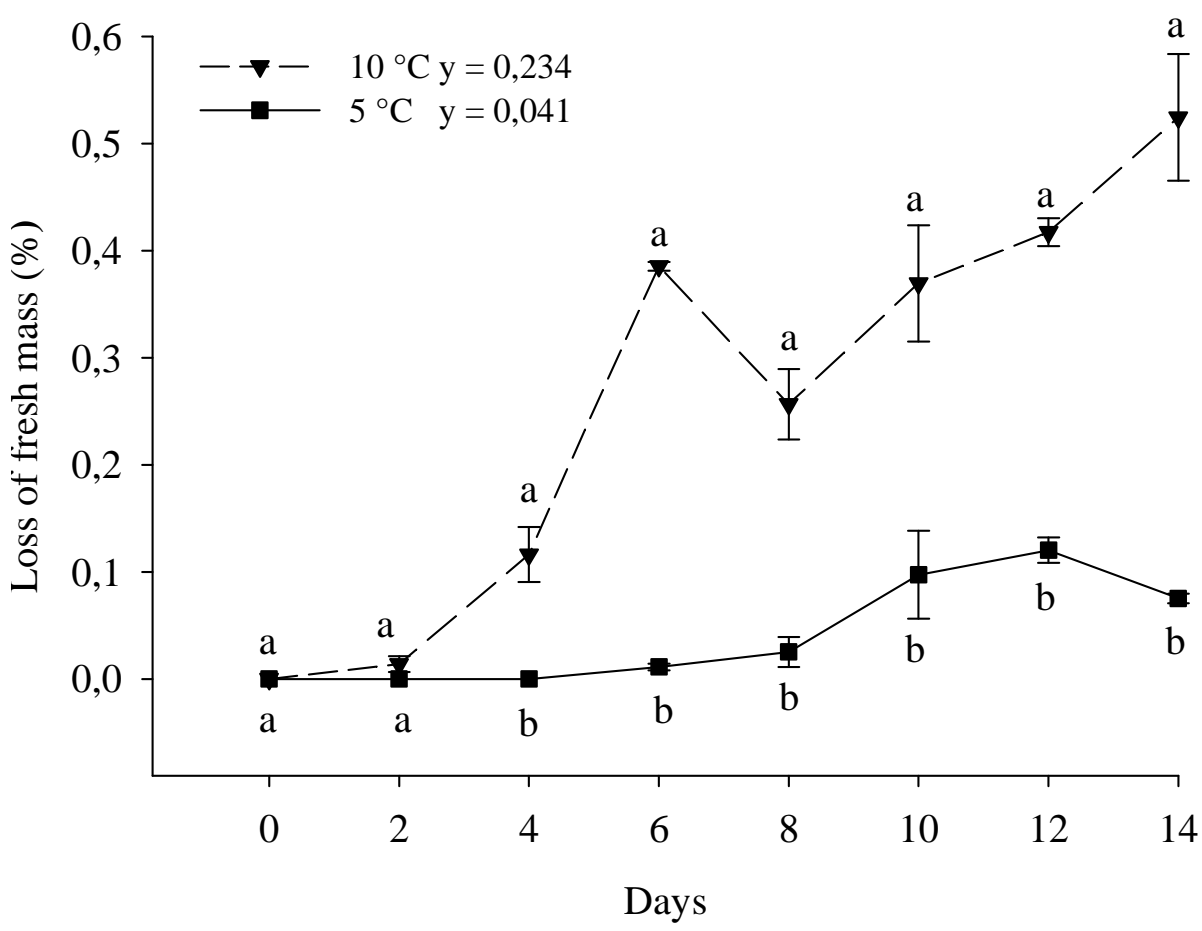

Figure 1. Loss of fresh mass in roots of yam minimally processed stored at 5 ( - - ) e $10 \pm 2{ }^{\circ} \mathrm{C}(\boldsymbol{\rightarrow -}$ ) for $0,2,4,6,8,10,12$ and 14 days. Serra Talhada - PE, UFRPEUAST, 2014. The vertical bars in graphic represent the standard deviation from the mean and the minimal significant difference (MSD) at $5 \%$. Data for three replications. Equal letters, that compare temperatures one the same day of conservation, they did not differ significantly by Tukey test at $5 \%$ probability. 
The storage temperature of $10^{\circ} \mathrm{C}$ may have intensified fresh weight loss due to increased metabolic activity. Increased weight loss was expected in minimally processed products as a result of increased water loss following cutting (BRECHT, 1995).

Fresh weight loss of yam kept at $5^{\circ} \mathrm{C}$ did not exceed $0.08 \%$, which was well below the results observed by Donegá et al. (2013) who found a loss of $0.8 \%$, in minimally processed yam packed in a polyvinyl chloride (PVC) film under the same temperature. We found that even considering the loss of fresh weight, storing yam at $5^{\circ} \mathrm{C}$ did not result in diminished quality as the starch deposition on the surface prevented the slices from drying-out. Donegá et al. (2013) observed similar results, however, PVC was used as packing material, which has lower thickness than our multilayer nylon packages and could have had influence on the findings.

Baking time of minimally processed yam decreased with storage time at both temperatures tested (Figure 2). Moreover, the reduction in baking time was more intense in yam stored at $5^{\circ} \mathrm{C}$ than in yam stored at $10^{\circ} \mathrm{C}$. Significant differences in baking time between storage temperatures were observed from the fourth day of storage. Initial average baking time was $18.14 \mathrm{~min}$. After 14 days of storage, baking time was reduced to $15 \mathrm{~min}$ for yam kept at $5^{\circ} \mathrm{C}$ and to $11.67 \mathrm{~min}$ for yam kept at $10^{\circ} \mathrm{C}$.

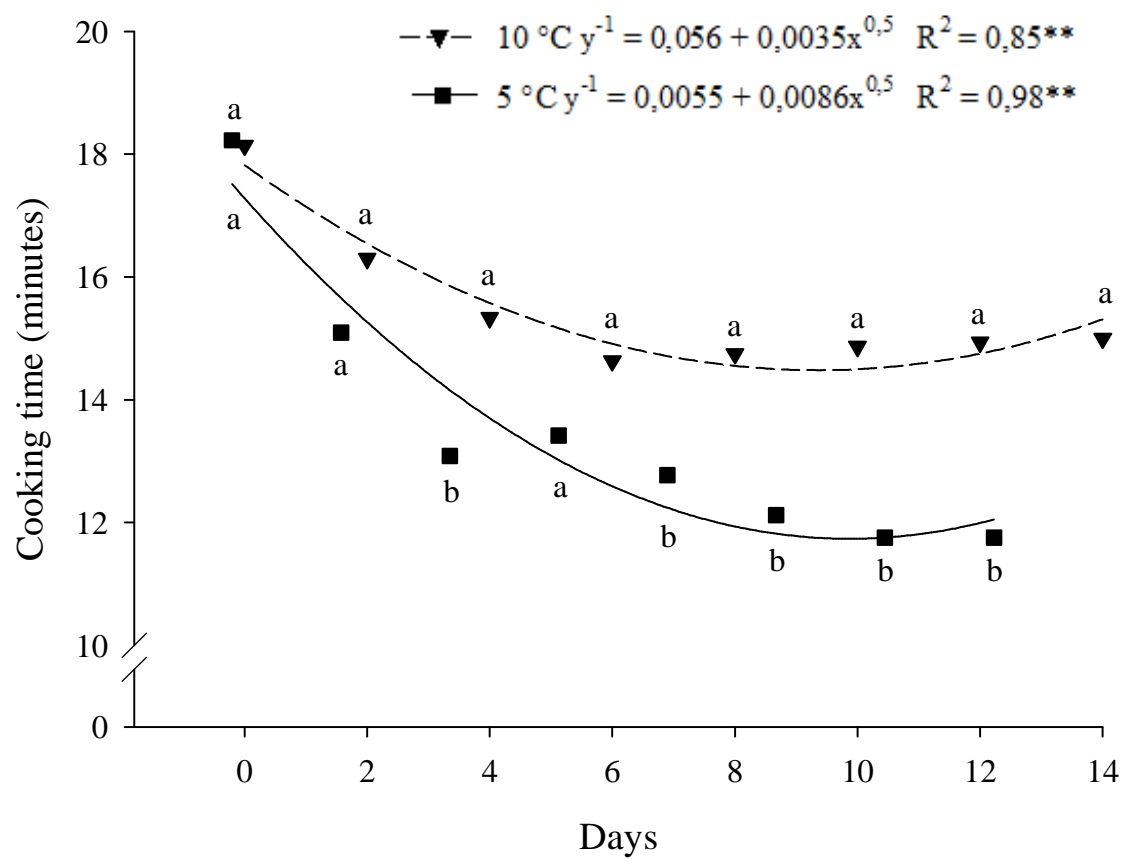

Figure 2. Cooking time in roots of yam minimally processed stored at 5 ( - ) e 10 $\pm 2{ }^{\circ} \mathrm{C}(\longrightarrow \rightarrow-)$ for $0,2,4,6,8,10,12$ and 14 days. Serra Talhada-PE, UFRPE-UAST, 2014. Equal letters, that compare temperatures one the same day of conservation, they did not differ significantly by Tukey test at $5 \%$ probability.

Longer baking times of minimally processed yam stored at $10^{\circ} \mathrm{C}$ can be related to higher dehydration at this temperature (Fig 1).

In a similar experiment with beans (Phaseolus vulgaris L.), Coelho et al. (2008) found that the baking time was influenced by the hydration rate of the beans. Therefore, it is possible that yam stored at $10^{\circ} \mathrm{C}$ may have taken longer to absorb water during the baking process, therefore increasing the time required to reach the baking temperature. Furthermore, the temperature of $10^{\circ} \mathrm{C}$ may have boosted some defence mechanisms, causing increased lignin deposition in the walls of injured cells and therefore, hindering rehydration of the yam slices.

Polyphenoloxidases and peroxidase activies increased during yam storage at both temperatures (Figure 3). Slices stored at $10^{\circ} \mathrm{C}$ had significantly higher polyphenoloxidase and peroxidase activities from day two onwards. Menolli et al. (2008) observed similar results in baroa-potatoes (Arracacia xanthorrhiza). It might be possible that the slices stored at $10^{\circ} \mathrm{C}$ had higher respiration rates and therefore accumulated more $\mathrm{CO}_{2}$, which leads to an increase in polyphenoloxidase activity. 

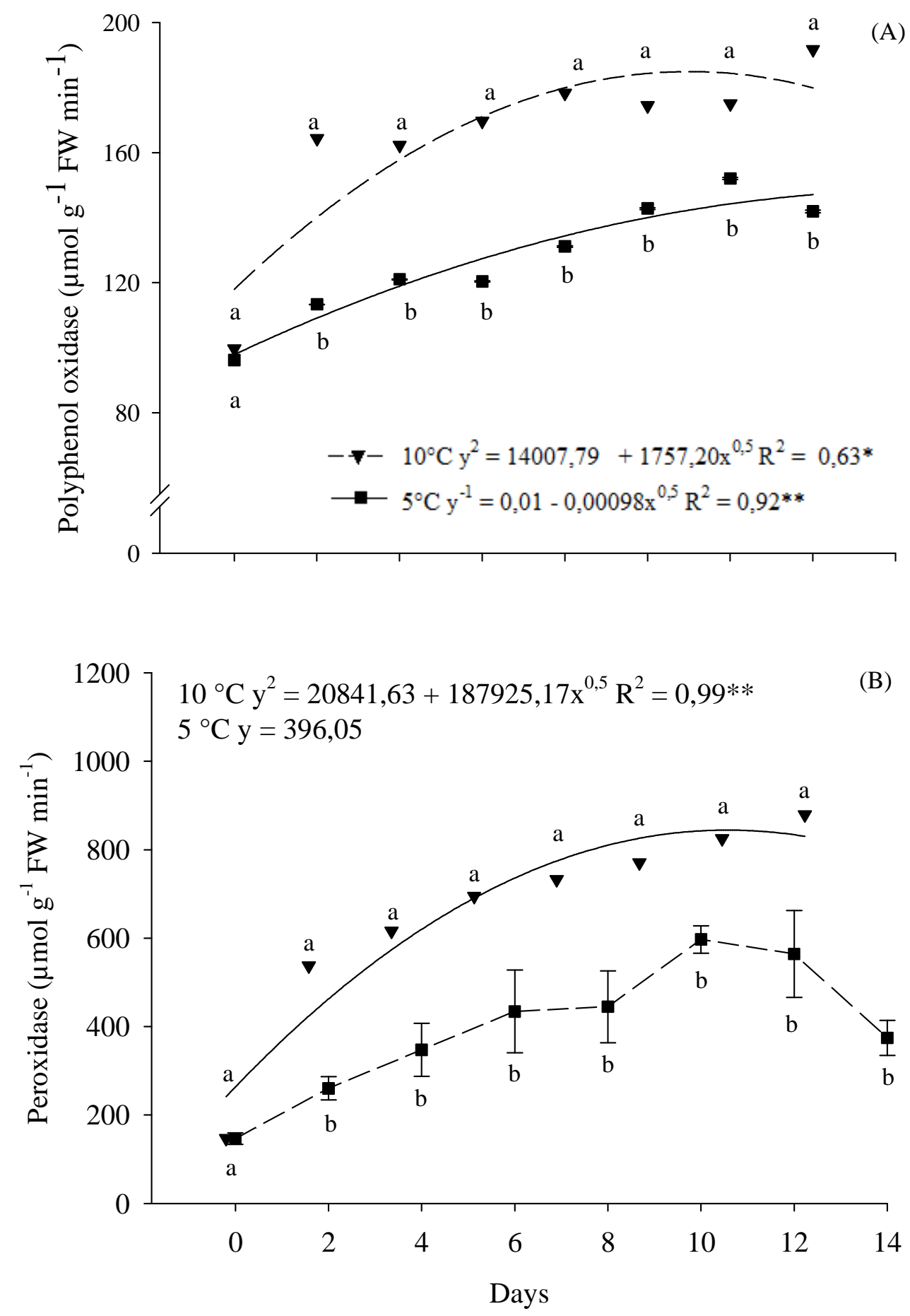

Figure 3. Polyphenol oxidase (A) and peroxidase activity (B) in roots of yam minimally processed stored at 5 ( $\longrightarrow$ ) e $10 \pm 2{ }^{\circ} \mathrm{C}(\longrightarrow \rightarrow-)$ ) for $0,2,4,6,8,10,12$ and 14 days. Serra Talhada - PE, UFRPE-UAST, 2014. The vertical bars in graphic B represent the standard deviation from the mean and the minimal significant difference (MSD) at $5 \%$. Data for three replications. Equal letters, that compare temperatures one the same day of conservation, they did not differ significantly by Tukey test at $5 \%$ probability.

In yam, peroxidase activities increase after peeling (OMIDIJI; OTUBU, 2006). In our study, the increased activities of polyphenoloxidase and peroxidase may be related to the darkening of the slices during storage (see figure 7).

Soluble phenol concentration of yam stored at 
5 and $10^{\circ} \mathrm{C}$ increased with storage, with significant differences from day six onwards (Figure 4).

Yam stored at $5^{\circ} \mathrm{C}$ showed higher mean values of total soluble phenol than yam stored at $5^{\circ}$ C. Furtado (2013) found similar results in minimally processed yam stored at $8^{\circ} \mathrm{C}$.

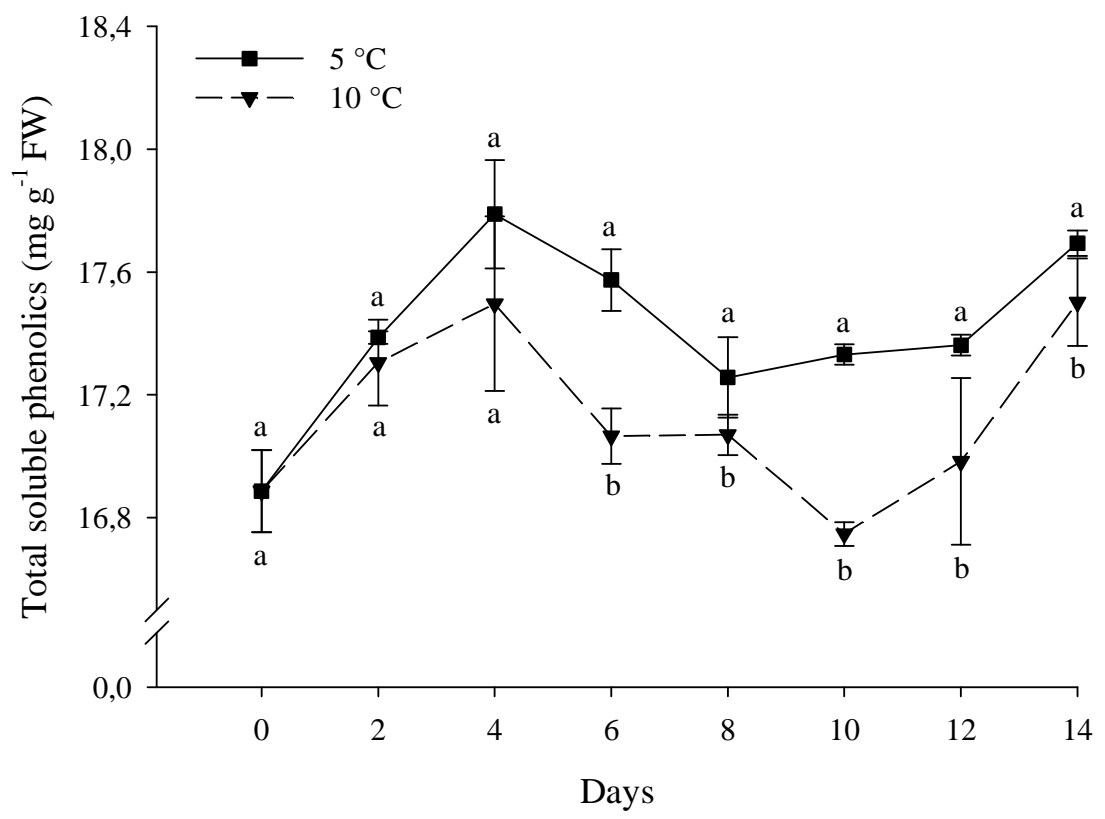

Figure 4. Total soluble phenols in roots of yam minimally processed stored at 5 ( - ) e $10 \pm 2{ }^{\circ} \mathrm{C}(\longrightarrow \rightarrow-)$ for $0,2,4,6,8,10,12$ and 14 days. Serra Talhada PE, UFRPE-UAST, 2014. The vertical bars in graphic represent the standard deviation from the mean and the minimal significant difference (MSD) at $5 \%$. Data for three replications. Equal letters, that compare temperatures one the same day of conservation, they did not differ significantly by Tukey test at $5 \%$ probability.

Baroa-potatoes stored at 5 and $10^{\circ} \mathrm{C}$ showed increased amount of total soluble phenols and a higher occurance of dark spots, even with increase in polyphenoloxidase and peroxidase activity (MENOLLI et al., 2008). Medeiros (2009) associates increase in polyphenoloxidase activity with increased total soluble phenols. However, increased concentration of total soluble phenols in yam slices stored at $5^{\circ} \mathrm{C}$ (Figure 5), did not result in increased polyphenoloxidase and peroxidase activities in our study. These enzymes use total soluble phenols as substrate (WATADA; ABE; YAMUCHI, 1990), which may have led to higher oxidation rates in slices stored at $10^{\circ} \mathrm{C}$; Freire et al. (2015) observed similar findigs in minimally processed table cassava (Manihot esculenta). Furthermore, the relatively low temperature of $5^{\circ} \mathrm{C}$ may have promoted chilling injury and consequently a greater production of total soluble phenols; this was also observed by Menolli et al. (2008).

Antioxidant capacity of minimally processed yam stored at 5 and $10^{\circ} \mathrm{C}$ decreased with storage time. Yam kept at $5^{\circ} \mathrm{C}$ showed reduction in antioxidant capacity by $47.7 \%$ compared to $50.29 \%$ reduction in yam stored at $10^{\circ} \mathrm{C}$ (Figure 5).

Yam stored at $5^{\circ} \mathrm{C}$ had higher antioxidant capacity from the day two of storage, but the difference in antioxidant capacity was only significant on days two and four (Figure 5).

Total soluble phenols are highly correlated with the antioxidant capacity of plant tissue, and total soluble phenols may have reacted with the reactive oxygen species (ROS) (FERRARI; TORRES, 2003) acting as antioxidant.

Catalase activity in yam stored at $5^{\circ} \mathrm{C}$ increased with storage time (Figure 6). Storage at $10^{\circ} \mathrm{C}$ resulted in lower catalase activities. However, in contrast to peroxidase activity, which was higher in yam stored at $10^{\circ} \mathrm{C}$, we found no significant difference in catalase activity between the two temperatures (Figure 3). This indicates that peroxidases consumed more hydrogen peroxide $\left(\mathrm{H}_{2} \mathrm{O}_{2}\right)$ at $10^{\circ} \mathrm{C}$. This was not observed in the case of catalases, which also use $\mathrm{H}_{2} \mathrm{O}_{2}$ as a substrate. 


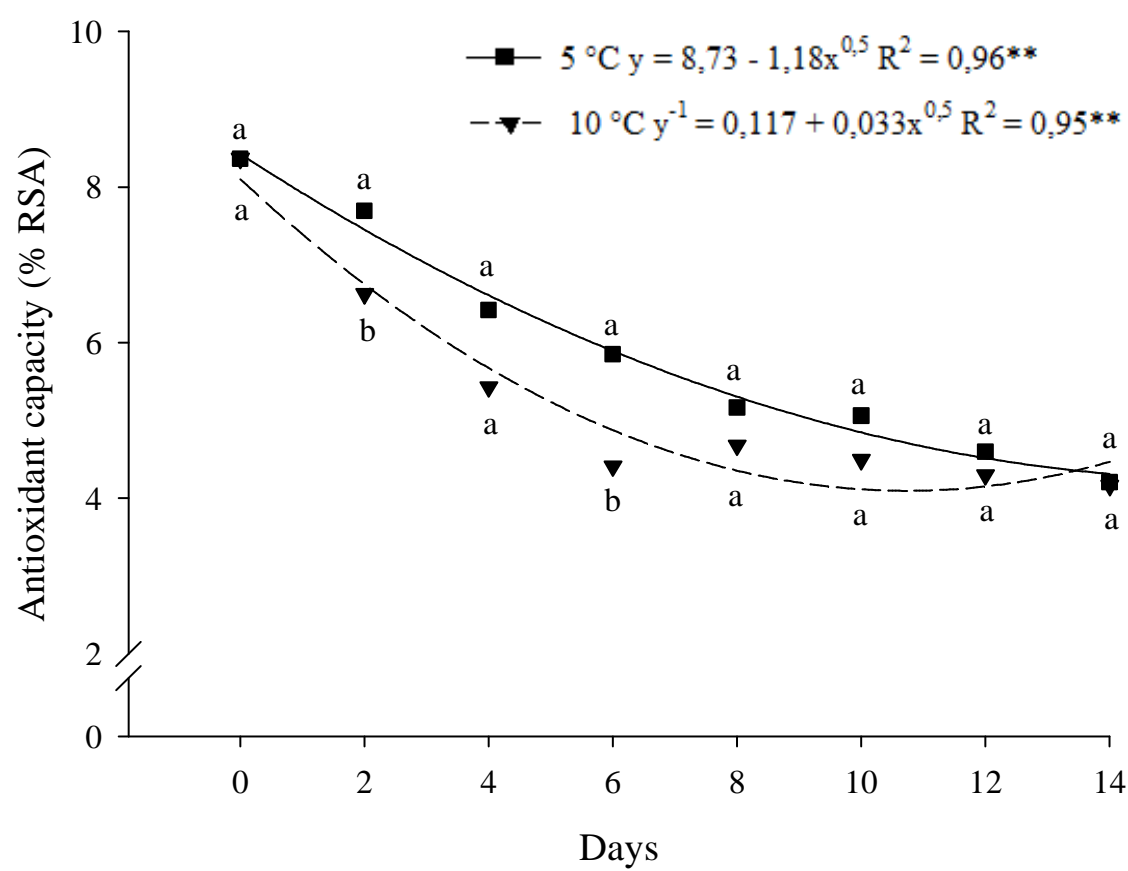

Figure 5. Antioxidant capacity in roots of yam minimally processed stored at 5 ( - ) e $10 \pm 2{ }^{\circ} \mathrm{C}\left(\longrightarrow \boldsymbol{\longrightarrow}^{-}\right.$) for $0,2,4,6,8,10,12$ and 14 days. Serra Talhada - PE, UFRPE-UAST, 2014. Equal letters, that compare temperatures one the same day of conservation, they did not differ significantly by Tukey test at $5 \%$ probability.

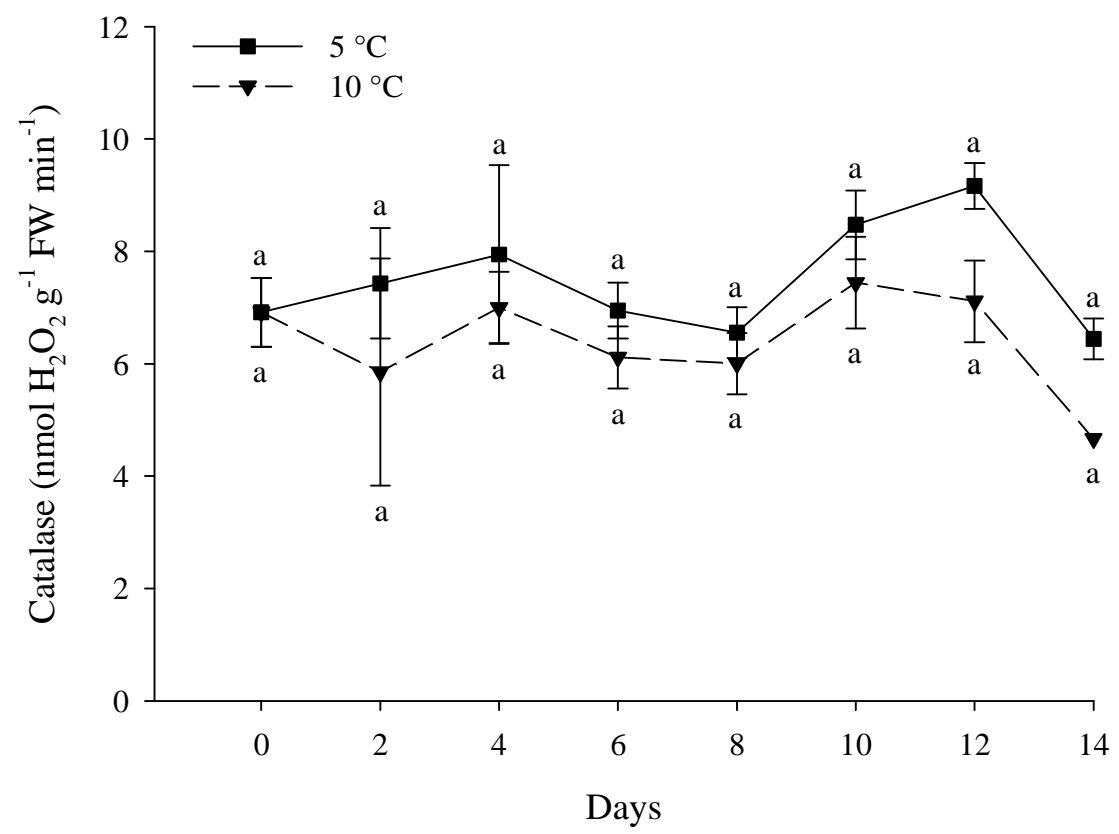

Figure 6. Catalase activity in roots of yam minimally processed stored at 5 ( - - ) e

$10 \pm 2{ }^{\circ} \mathrm{C}(\longrightarrow \rightarrow-)$ for $0,2,4,6,8,10,12$ and 14 days. Serra Talhada - PE, UFRPEUAST, 2014. The vertical bars in graphic B represent the standard deviation from the mean and the minimal significant difference (MSD) at $5 \%$. Data for three replications. Equal letters, that compare temperatures one the same day of conservation, they did not differ significantly by Tukey test at $5 \%$ probability. 
In terms of visual analysis, yam stored at $5^{\circ} \mathrm{C}$ received the highest scores throughout storage time and did not exceed the acceptance limit (Figure 7). In contrast, yam stored at $10^{\circ} \mathrm{C}$ received lower scores throughout storage time and reached the acceptance limit after a storage time of 14 days (Figure 7).

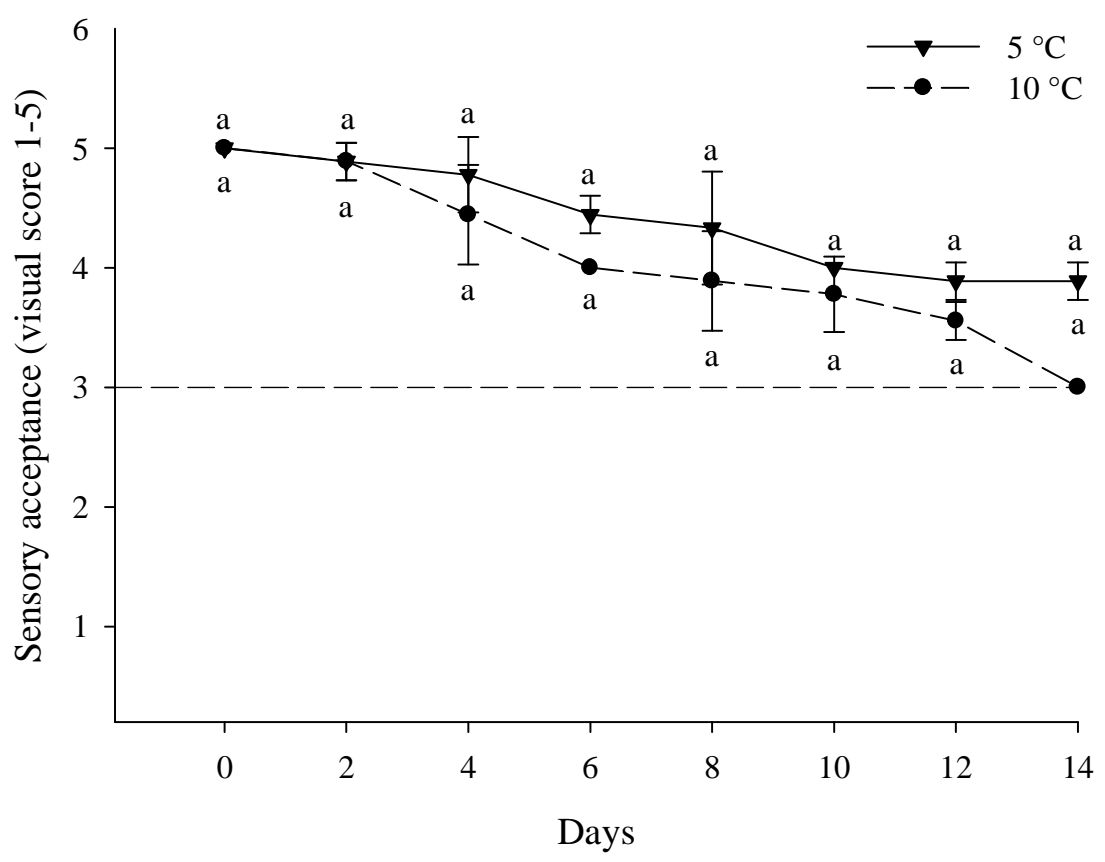

Figure 7. Visual analysis (sensory acceptance) in roots of yam minimally processed stored at $5\left(\longrightarrow \boldsymbol{C}^{-}\right)$) e $10 \pm 2{ }^{\circ} \mathrm{C}(-\rightarrow-$ ) for $0,2,4,6,8,10,12$ and 14 days. Serra Talhada - PE, UFRPE-UAST, 2014. The vertical bars in graphic represent the standard deviation from the mean and the minimal significant difference (MSD) at $5 \%$. Data for three replications. Equal letters, that compare temperatures one the same day of conservation, they did not differ significantly by Tukey test at $5 \%$ probability. The horizontal dashed line represents the limit for marketing, it is related to note 3.

The decreased quality in yam slices stored at both temperatures may be related to increased polyphenoloxidase and peroxidase activities (Figure 3 ), resulting in the production of insoluble and dark pigments, melanins, which lead to a darkening of the slices (LAMIKANRA, 2002). Additionally, yam stored at $10^{\circ} \mathrm{C}$ had gas accumulated in the packaging, which was not observed for yam stored at $5^{\circ} \mathrm{C}$.

Although there was no sigificant difference in visual appearance, temperature is a factor that can influence the visual quality of minimally processed yam.

In all samples, there was no incidence of psicotrophic bacteria of the genus Pseudomonas (Table 1). This result may be related to the use of multilayer nylon packaging, which has a low permeability for $\mathrm{O}_{2}$ and may therefore have provided inadequate atmosphere for Pseudomonas. Most likely, it has also led to lower occurance of oxidative damage in cells and tissues (SILLANKORVA, 2004). 
Table 1. Incidence of Pseudomonas sp. in roots of yam minimally processed stored at 5 e $10 \pm 2{ }^{\circ} \mathrm{C}$ for $0,2,4,6,8,10,12$ and 14 days. Serra Talhada - PE, UFRPE-UAST, 2014.

\begin{tabular}{|c|c|c|}
\hline \multirow[t]{2}{*}{ Days } & \multicolumn{2}{|c|}{ Temperature $\left({ }^{\circ} \mathrm{C}\right)$} \\
\hline & $5 \pm 2{ }^{\circ} \mathrm{C}$ & $10 \pm 2{ }^{\circ} \mathrm{C}$ \\
\hline 0 & & \\
\hline 2 & & \\
\hline 4 & & \\
\hline 6 & & \\
\hline 8 & & \\
\hline 10 & & \\
\hline 12 & & \\
\hline 14 & & \\
\hline
\end{tabular}

\section{CONCLUSIONS}

In general, minimally processed yam stored in $15 \mu \mathrm{m}$ thick multilayer nylon packaging at $10^{\circ} \mathrm{C}$ can be kept for up to six days. In case, yam needs to be stored for up to 14 days, a temperature of $5^{\circ} \mathrm{C}$ is more appropriate.

\section{REFERENCES}

ANDRADE, D. P. Cultivares de mandioca de mesa e idades de colheita: avaliação agronômica e adequação ao processamento mínimo. 2013. $98 \mathrm{f}$. Dissertação (Mestrado em Produção Vegetal) Universidade Federal Rural de Pernambuco, Serra Talhada, 2013. 
ANDRADE, R. D. et al. Almacenamiento de trozos de ñame (Dioscorea rotundata Poir) en Atmósferas Modificadas. Informacíon tecnologica, La Serena, v. 23, n. 4, p., 2012.

BEERS JUNIOR, R. F.; SIZER, I. W. A spectrophotometric method for measuring the breakdown of hydrogen peroxidase by catalase. The Journal of Biological Chemistry, Rockville, v. 195, n. 2, p. 133-140, 1952.

BRAND-WILIAMS， W.; CUVELIER， M.E.; BERSET, C. Use of a free radical method to evaluate antioxidant activity. Food Science and Technology, Campinas, v. 28, n., p. 25-30, 1995.

BRECHT, J. K. Physiology of lightly processed fruits and vegetables. HortScience, Virgínia, v. 30, n. 1, p. 18-22, 1995.

BRITO, T. T. Determinação das etapas, fluxograma do processamento e estudo da conservação de inhame minimamente processado. 2011. 92 f. Dissertação (Mestrado em Ciência e Tecnologia de Alimentos) - Universidade Federal de Sergipe, Aracaju, 2011.

COELHO, A. F. S. Qualidade de alface Americana (Lactuca sativa L.) minimamente processada. 2001. 104 f. Dissertação (Mestrado em Ciência dos Alimentos) - Universidade Federal de Minas Gerais, Belo Horizonte, 2001.

COELHO, C. M. M. et al. Tempo de cocção de grãos de feijão em função do tipo d'água. Ciência Agrotecnologia, Lavras, v. 33, n. 2, p. 560-566, 2008.

DONEGÁ, M. A. et al. Fresh cut yam stored under different temperatures. Horticultura Brasileira, Botucatu, v. 31, n., p. 248-254. 2013.

FAO. FAOSTAT - Agricultural statistics database. [online]. Rome: World agricultural Information centre 2011. Disponível em: <http:// www.fao.org.br>. Acesso em: 18 dez. 2013.

FATIBELLO-FILHO, O.; VIEIRA, I. C. Uso analítico de tecidos e de extratos brutos vegetais como fonte enzimática. Química Nova, São Paulo, v. 25 , n. 3, p. 455-464, 2002.

FERRARI, C. K. B.; TORRES, E. A. F. S. Biochemical pharmacology of functional foods and prevention of chronic diseases of aging. Biomedicine \& Pharmacotherapy, Amsterdam, v. 57, n., p. 251-260, 2003.

FREIRE et al. Activity of oxidative enzymes involved in the browning of minimally processed sweet cassava (Manihot esculenta Crantz). Australian Journal of Crop Science, Melbourne, v. 9, n. 4, p. 296-302, 2015.

FREIRE, C. S. et al. Qualidade de raízes de mandioca de mesa minimamente processada nos formatos Minitolete e Rubiene. Revista Caatinga, Mossoró, v. 27, n. 4, p. 95 - 102, 2014.

FURTADO, M. C. Ação de revestimento comestível a base de amido e de antioxidante na conservação de inhame (Dioscorea spp.) minimamente processado. 2013. 76 f. Dissertação (Mestrado em Ciência e Tecnologia de Alimentos) Universidade Federal de Sergipe, Aracaju, 2013.

HOWARD, L. R.; GRIFFIN, L. E. Lignin formation and surface discoloration of minimaly processed carrot sticks. Journal Food Science, Malden, v. 58, n. 5, p. 1065-7, 1993.

JANDEL SCIENTIFIC. Tablecurve: curve fitting software. Corte madeira, CA: JANDEL SCIENTIFIC, $1991.280 \mathrm{p}$.

LAMIKANRA, O. Fresh-cut fruits and vegetables: science, technology and market. 1. ed. Boca Raton, London, New York e Washington: CRC Press, 2002, $452 \mathrm{p}$.

MEDEIROS, E. A. A. Deterioração pós-colheita de mandioca minimamente processada. $2009.113 \mathrm{f}$. Tese de Doutorado (Doutorado em Fisiologia Vegetal) - Universidade Federal de Viçosa, Viçosa, 2009.

MENOLLI, L. N. et al. Atuação das enzimas oxidativas no escurecimento causado pela injúria por frio em raízes de batata-baroa. Acta Scientiarum. Agronomy, Maringá, v. 30, n. 1, p. 57-63, 2008.

OMIDIJI, J.; OTUBU, O. The contribution of an ionic peroxidase isozyme to enzyme-mediated browning in Dioscorea esculenta L. tubers. Pakistan Journal of Nutrition, Sargodha Road, v. 5 n. 5, p. 478-480, 2006.

PEIXOTO NETO, P. A. S. et al. Inhame: o Nordeste Fértil. 1. ed. Maceió, AL: EDUFAL, 2000. $88 \mathrm{p}$.

REYES, L. F.; VILLARREAL, J. E.; CISNEROSZEVALLOS, L. The increase in antioxidant capacity after wounding depends on the type of fruit or vegetable tissue. Food Chemistry, Amsterdam, v. 101, n., p. 1254-1262, 2007

SÁNCHEZ-MORENO, C. Review: methods used to evaluate the free radical scavenging activity in foods 
and biological systems. Food Science and

Technology International, Valencia, v. 8, n., p. 121 $-137,2002$.

SANTOS, E. S. A. et al. Inhame (Dioscorea sp.) tecnologia de produção e preservação ambiental. Tecnologia \& Ciência Agropecuária, João Pessoa, v. 1, n., p. 31-36, 2007.

SILLANKORVA, S. A. Utilização de Bacteriófagos no Controlo de Células Suspensas e Biofilmes de Pseudomonas fluorescens. 2004. 125 f. Dissertação (Mestrado em Tecnologia do Ambiente) - Universidade do Minho, Braga, 2004.

SILVA, E. Estudos da atividade enzimática da polifenoloxidase e peroxidase em algumas frutas e hortaliças 'in natura' e processadas. 1981. $108 \mathrm{f}$. Dissertação (Mestrado em Tecnologia de Alimentos) - Escola Superior de Agricultura de Luiz de Queiroz, Piracicaba, 1981.

SILVA, M. V.; ROSA, C. I. L. F.; VILAS BOAS, E. V. B. Conceitos e métodos de controle do escurecimento enzimático no processamento mínimo de frutas e hortaliças. Boletim do CEPPA, Curitiba, v. 27, n. 1, p. 83-96, 2009.

SILVA, E. F. Marcadores bioquímicos e fisiológicos envolvidos na conservação de Inhame (Dioscorea Spp.) minimamente processado. 2014. 109 f. Dissertação (Mestrado em Produção Vegetal) - Universidade Federal Rural de Pernambuco, Serra Talhada-PE.

SIMÕES, A. N.; MOREIRA, S. I.; MOSQUIM, P. R.; SOARES, N. F.; PUSCHMANN, R. Effect of conservation temperature on quality and phenolic metabolism of intact and minimally processed kale leafs. Acta Scientiarum. Maringá, v. 37, p. 101-107, 2015.

VELIOGLU, Y. S. et al. Antioxidant activity and total phenolics in selected fruits, vegetables, and grain products. Journal of Agricultural and Food Chemistry, Columbus, v. 46, n. 10, p. 4113-4117, 1998.

$\mathrm{XU}$, J. et al. Enhanced reactive oxygen species scavenging by overproduction of superoxide dismutase and catalase delays postharvest physiological deterioration of cassava storage roots. Plant Physiology, Rockville, v. 161, p. 1517-1528, 2013.

WATADA, A. E.; ABE, K.; YAMUCHI, N. Physiological activities of partially processed fruits and vegetables. Food Technology, Chicago, v. 44, p. 116-122. 1990. 